Revista Iberoamericana, Vol. LXXVII, Núms. 236-237, Julio-Diciembre 2011, 731-747

\title{
LA POESÍA POPULAR DE HÉCTOR MELÉNDEZ EN LA REVISTA TOPAZE
}

\author{
POR \\ JORGE RUEDA \\ Universidad de Santiago de Chile
}

Los discursos sociales son plurales. Compréndase por discurso social, acorde con Angenot, "todo aquello que se dice y se escribe en un estado de sociedad, todo lo que se imprime, todo lo que se habla y se representa hoy en los medios electrónicos. Todo lo que se narra y se argumenta, si se plantea que narrar y argumentar son los dos grandes modos de puesta en discurso" (17). Esta diversificación liga o distingue a muchos de ellos de la práctica significante dominante; sea uno u otro el caso, los variados registros discursivos de una sociedad, coexisten, se cruzan y se interfieren con los temas repertorios de un contexto histórico-cultural.

El caso del poeta popular Héctor Meléndez es un ejemplo de lo recién señalado. Como representante de la práctica popular y masiva, se desplazó de este subsistema discursivo al letrado-ilustrado de una revista de análisis político. Su acción artística generó, por ende, una dinámica de articulación entre dos circuitos culturales. Examinar la obra de Meléndez en este marco obliga, entonces, a revisar los aspectos temáticos de su poesía y considerar la incorporación que la revista hizo de ellos como un fenómeno democrático (en el sentido de recepción de un registro heterogéneo).

En la diversidad de condiciones súper-estructurales o coyunturales en que se producen, las normas, contenidos de formas comunicacionales legitimadas por los circuitos oficiales, también las censuras, novedades y escisiones, dialogan en una intersignificación plural: "El carácter estructural de los procesos de comunicación masiva y el entramado mercantil de los medios van a encontrar en la problemática de lo ideológico un campo estratégico de convergencia para el análisis” (Martín-Barbero 53, cursiva en el original). Demostrar esta proposición en la matriz total de un discurso social es una tarea compleja. Implicaría revisar y describir el programa global de los discursos y contradiscursos sociales de un período histórico determinado. No obstante, sirva como ejemplo, la manera de significar que tuvo en Chile la revista Topaze. Ésta, como soporte letrado, integró acentos y formas (crítica satírica y análisis políticos, por 
sobre otras) los cuales, más en el disenso que en la dependencia reproductiva de cierta ideología oficial, representó una tópica referida a temas globales de una época del país. Un caso ilustrativo fue Héctor Meléndez, quien estuvo ligado a la revista en la primera década de edición. Durante este período produjo, como lo demostrará el presente artículo, un trabajo cultural distinto. Desde la perspectiva del sujeto del pueblo, su personaje Juan Verdejo expresó en versos las imágenes y visiones de los sectores subalternos. Como consecuencia de esto, Meléndez constituyó un registro de resistencia esperanzada ante las distintas problemáticas vividas por los sectores sociales subproletarios.

Entre el 21 de octubre de 1931 y el 3 de julio de 1942, Meléndez dio vida -y voz- a Juan Verdejo, personaje emblemático del roto, el chileno pobre y marginado en el espacio urbano. Por casi doce años, sus “Tallas populares”, nombre inicial de la página de Meléndez (siempre escrita en estrofas de ocho versos octosílabos), ampliaron la línea satírica de Topaze al incorporar las motivaciones silenciadas de los grupos sociales despojados del poder oficial. Al interior de este proceso, el lector reconoció la manera cómo un recurso de este tipo criticaba e invertía diversos aspectos del campo interdiscursivo de una tópica nacional: sistemas ideológicos, política y personajes públicos, poderes sociales, prejuicios de clases, creencias morales del tipo dominante, etc.

Rastrear el posible origen de Verdejo lleva a reconocer un imaginario colectivo que fue mantenido a nivel de sub-cultura por el sistema cultural ilustrado-hegemónico. Para J. Montealegre los primeros antecedentes de Verdejo se remontarían a 1902, puntualmente a una crónica policial titulada "El hombre más feo de Chile". En ella, señala a Manuel Pérez Verdejo, denominado simplemente como Verdejo en el resto de la publicación, como "natural de Maipú, gañan de oficio y con 38 años sobre las costillas es probablemente, como él mismo se apresura a reconocerlo, el hombre más feo de Chile” (Sucesos 14). Incorporado al artículo se encuentra una referencia esclarecedora dada por Montealegre: "Era malísimo, pero gracioso. Sus gracias eran contadas por la lira popular, que informaba en versos la crónica roja de la época” (Sucesos 22). Verdejo representa al hombre del pueblo, con un rasgo especial, el don de hacer reír, a pesar de su condición desmedrada. Nótese el discurso tópico del artículo referido, donde se observa una serie de conceptos que hacen del sujeto aludido una imagen de bestialidad:

Sin conocer padre ni madre, criado a toda intemperie en los vericuetos de Maipú, este infeliz no ha hecho siquiera la ruda aunque doméstica vida del gañán de oficio, del verdadero gañán que trabaja y gana un jornal; sino la vida semi-salvaje de una bestezuela en el monte, durmiendo en el santo suelo, guareciéndose de lluvia bajo la copa de los árboles o en la primera choza; alimentándose de cualquier modo, hozando tierra siempre, siempre en tinieblas y sin conciencia alguna del bien y del mal. Sin embargo, hay en ese desgraciado una predisposición al buen humor y a la chirigota, que recrea la existencia, bajo su grosera epidermis, de cierta chispa natural. Acaso la vis cómica del rotito que por zote y malaventurado que sea, siempre encuentra una salida con sus dichos para alejarse de las penas. (Sucesos 15)

Revista Iberoamericana, Vol. LXXVII, Núms. 236-237, Julio-Diciembre 2011, 731-747 ISSN 0034-9631 (Impreso) 
Fue desde este personaje marcadamente azotado por la vida y estigmatizado por el discurso escrito como el del artículo citado que, según Montealegre, pudo Meléndez inspirarse para crear la figura de Juan Verdejo. Lo que importa recalcar es que, de ser válida esta hipótesis, la escritura del poeta cobra mayor importancia, ya que se vuelve un registro desjerarquizado, que invierte las fobias y los principios de exclusión generados desde la palabra hegemónica.

Respecto de Héctor Meléndez, poco se conoce de su vida. Se sabe su condición de poeta, porque hacia 1918 ya escribía en un periódico de la nortina ciudad de Antofagasta de nombre El pollo Tejada. Aquí publicó una columna de lira popular denominada "Aventuras de un roto coquimbano". Posteriormente esta columna la tituló “Aventuras de Juan Perales”. Con este primer personaje, Meléndez representaría lo esencial de la visión de los pobres y excluidos -los rotos- en páginas de la prensa, a quienes retrató a través de formas típicas de su habla y de sus costumbres.

Posterior a Juan Perales fue Juan Verdejo quien heredó cada uno de aquellos rasgos. Sin embargo, entre uno y otro hubo diferencias en la construcción del personaje. Mientras Juan Perales, narraba sus múltiples aventuras y picardías en Coquimbo, Verdejo se entrometió, mediante su opinión, en la política nacional. El repertorio de creencias, costumbres y percepciones de los sectores sociales, no siempre incorporados a las formas discursivas canónicas se hizo, en los versos que Meléndez escribió, identidad cultural.

El conocimiento que tuvo Héctor Meléndez de la poesía de raíz popular quedó, además, demostrada en la propia Revista Topaze. Entre 1938 y 1942 incorporó abundantes "Versos de Ciego" los cuales tienen como base el "romancero vulgar" (una manifestación literaria popular en la que los romances sirven de molde para la difusión de temas sensacionalistas). Éstos se conocen también como "literatura de cordel” y "romances de ciegos", ya que frecuentemente eran ciegos quienes los difundían por ferias o romerías. Los personajes más pobres, aquellos discriminados históricamente por el poder siempre interesado en mantener sus privilegios, pasaron a ser representados, sin idealismos ni nostalgias románticas, en este espacio comunicativo y, lo que resultó más significativo, se recuperaron sus auténticas visiones de mundo.

Posiblemente hacia fines de la segunda década del siglo xx, Héctor Meléndez ya vivía en Santiago de Chile. Entre 1925 y 1940 -años de la última producción del poeta-el país se caracterizó por una etapa de creciente concientización social, "en parte por el aumento considerable de la población proletaria minera y urbana aglutinada en organizaciones sindicales de izquierda bajo el liderazgo inicial de Luis Emilio Recabarren” (Guerra 101). Miles de pobres vivieron las miserables condiciones de la explotación laboral. Fue un período de tensión obrera. La ciudad aglutinó masas humanas mal alimentadas y enfermas. La tuberculosis hizo estragos y condenó a la muerte a hombres, mujeres y niños Ámbitos culturales como el de la creación literaria, el periodismo o algunos movimientos políticos no escaparon a la repercusión ideológica que tuvo la llamada “cuestión social”. En el fenómeno comunicativo de entrecruzamiento de discursos

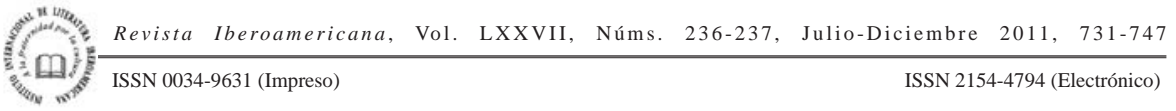


sociales, se puede decir que este ideologema constituyó la textualización de múltiples discursos interferidos. La Revolución Mexicana, por ejemplo, significó en Latinoamérica un referente ineludible a la hora de reivindicar los derechos de la gran masa de proletarios de la ciudad y campesinos que vivían en extrema pobreza e injusta explotación.

Sin ir más lejos, en Chile, un ejemplo evidente de este proceso se observa en la generación literaria de 1938. Muy distante de alcanzar una homogeneidad ideológica, la escritura de sus integrantes estuvo orientada a mostrar la descripción del entorno real, la revelación de lo propio y la denuncia de los males sociales:

El criollismo ofrece un documento antropológico de la idiosincrasia, las costumbres, las vestimentas y el hábitat particular de un sector del territorio chileno con el objetivo de fijar una esencia de lo nacional [...]. Es importante observar que dicho documento respondía a una visión burguesa de los sectores campesinos y obreros. La esencia de lo chileno era, entonces, un conjunto parcelizado de elementos tangibles observados desde la perspectiva exterior de un escritor de la clase media intelectual que tiene como receptores implícitos los estratos superiores del espacio urbano. (Guerra 101-3)

En este contexto, Héctor Meléndez, en su condición de poeta popular superó la marca de escritura burguesa e impostada (de circuito hegemónico culto, jerarquizado y de recepción intelectual), pues tuvo una relación directa con el "paisaje popular", tanto en lo cultural como en lo humano. De este modo, logró instalar en el discurso social escrito de la revista Topaze, las modalidades propias de una práctica significante de tipo heterogéneo de una tradición oral (un campo cultural-otro, vinculado al espacio de masas no ilustrado).

Por lo anterior, cuando en 1931 Meléndez situó a Juan Verdejo como figuracentro de una revista editada en Santiago de Chile y de circulación masiva (por tanto, de recepción diversificada), se alineó en cierta medida con la atmósfera criollista al valorar e incorporar en la escritura las masas rurales que buscaron en la ciudad mejores perspectivas. Verdejo fue una figura derivada de este origen: "Yo en ese tiempo vivía / con una tía en el campo” (Topaze $\mathrm{N}^{\circ}$ 27). ${ }^{1}$ No obstante, en Meléndez, la representación de los ámbitos de este mundo humano se perfiló como visión de vida.

II

Juan Verdejo apareció en la revista Topaze $\mathrm{N}^{\circ}$ 11. Con el título de "Las fiestas primaverales. Juan Verdejo ya tiene un disfraz", se dio comienzo a las tallas en versos

1 La revista Topaze no numeró sus páginas, de aquí que ellas no se consignen en las diversas citas intratextuales realizadas en el presente artículo. Se precisará, por tanto, la fecha de edición como dato complementario.

Revista Iberoamericana, Vol. LXXVII, Núms. 236-237, Julio-Diciembre 2011, 731-747 ISSN 0034-9631 (Impreso) ISSN 2154-4794 (Electrónico) 
octosílabos a través de los cuales el lector reconoció a Verdejo y su discurso. Esta primera etapa llega hasta el $\mathrm{N}^{\circ} 60$ de Topaze, del 28 de septiembre de 1932. Una interrupción de Meléndez en Topaze lo lleva como redactor de la revista Verdejo. De esta publicación circularon 32 números, desde el 4 de octubre de 1932 al 2 de mayo de 1933. Mediante un juego discursivo entre realidad y ficción, Juan Verdejo Larraín aparece como "Director Constitucional” de la revista. El pensamiento de Juan Verdejo, de la pluma de Meléndez, se retrata desde el primer número de esta nueva revista, donde el personaje aparece "Mandando el buque", según se titulan los versos iniciales. Cambiando su pasado tortuoso y pobre, Juan Verdejo agrega esta vez, como segundo apellido, el connotado Larraín; esto, con el fin de poseer renombre:

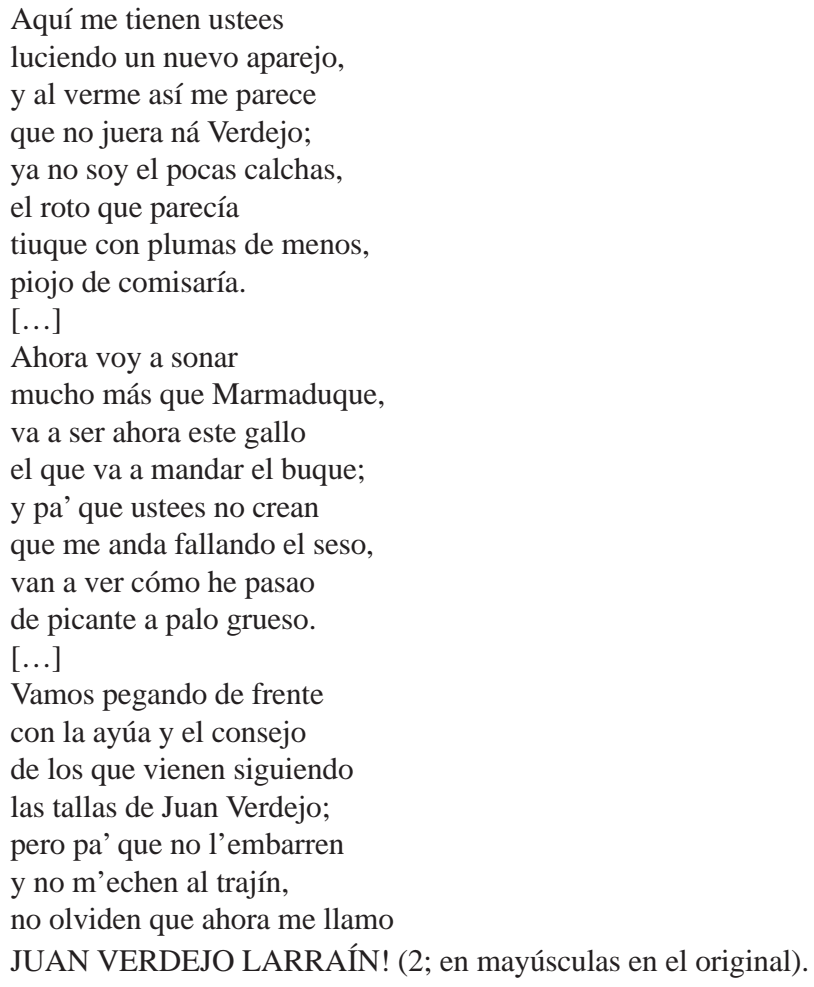

Durante el período de circulación de la revista Verdejo, el semanario Topaze incorporó como nuevo personaje a Juan Machuca. La reacción de Meléndez fue inmediata:

$\begin{array}{lllll}\text { ISSN 0034-9631 (Impreso) } & \text { ISSN 2154-4794 (Electrónico) }\end{array}$ 


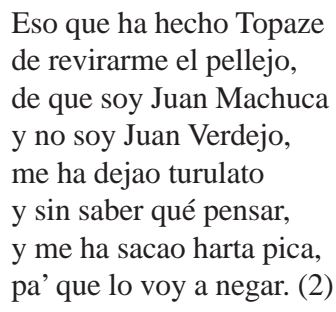

Y en junio de 1932, siempre en función de este hecho, Meléndez escribía:

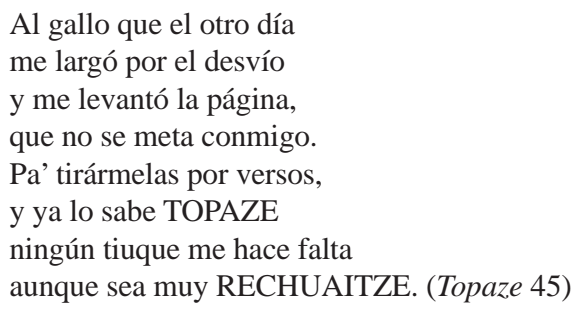

Las diferencias entre Verdejo y Machuca cesaron el 31 de mayo de 1933, fecha en que Héctor Meléndez posiciona definitivamente a Juan Verdejo en Topaze:

Ciertas cuestiones que a nadie

le interesan un pepino,

m' hicieron cambiar de pelo

y cambiarme el apellío;

pero como ya pasó

lo que me tuvo en un brete, sigo siendo el mismo de antes, el Juan Verdejo de siempre.

En esta casa nací

y en esta casa me crié

salí a conocer el mundo

y mecón que me clavé;

tirarme el salto yo solo

qué pecao abría sío

pero hay que ver que llevaba

a la patrona de tiro. (Topaze 95)

La permanencia definitiva de Meléndez en Topaze, a partir esta fecha, fue hasta el $N^{\circ}$ 514 de la revista, del 3 de julio de 1942, apenas dos meses antes de la muerte del poeta.

Revista Iberoamericana, Vol. LXXVII, Núms. 236-237, Julio-Diciembre 2011, $731-747$
ISSN 2154-4794 (Electrónico) 
De lo expuesto se desprende que Héctor Meléndez significó, para Topaze y el público lector de esta revista, la instalación de un registro sociodiscursivo inscrito en referencia temática cruzada con el discurso social de gravitación dominante. Sin embargo, el carácter contestatario y a la vez paródico de su registro se alzó, precisamente, cuando el discurso heterogéneo que lo distinguió confirmaba la dominancia de aquél último. Es así cómo, ligado al marco sociohistórico que lo engloba, Meléndez y su personaje configuran un discurso a partir una serie de imágenes-tópicos.

Por lo anterior, la realidad histórica se representa como una fuente de conflicto, como un escenario político ineficaz frente a las demandas de la mayoría y, por esta misma causa, motivo principal de injusticias:

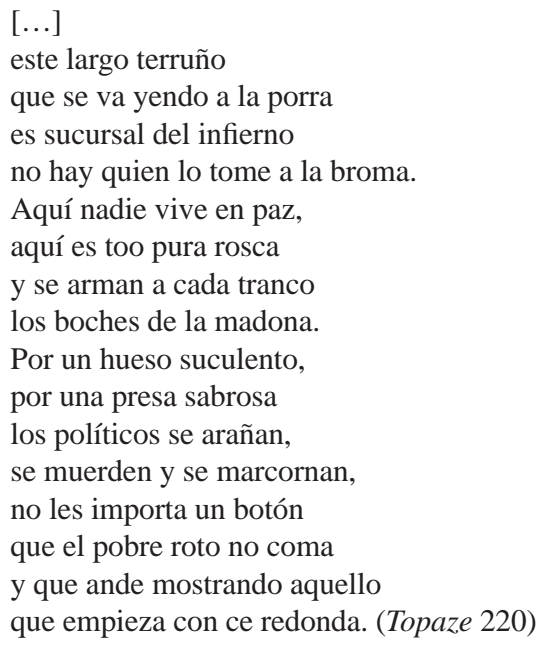

Frente a tales dilemas, los representantes de los diversos partidos políticos de la época, todos en colusión desde la perspectiva del discurso heterogéneo de Meléndez, se hacen símbolo del poder establecido por esta clase. En los versos que siguen, la denotación musical que alude el concepto de "banda”, no deja de percibirse la connotación paródica de "pandilla”, "bandada de ladrones" con la cual el hablante identifica a los grupos ideológicos que protagonizaban la vida política del país. Como tal, se perciben mediante imágenes de fuerzas fatalmente engañosas y rápidamente pervertidos:

Los biatos, los raicales,

los liberales, los moeras,

toos forman en la banda

y son ellos los que tocan

mientras bailan en las nubes,

ISSN 0034-9631 (Impreso) 
La escritura de Meléndez revela, en el texto, un espacio donde las contradicciones se acumulan, el desorden crece, las huelgas se multiplican y se exacerban los conflictos sociales. Este panorama condiciona un discurso que refleja la toma de conciencia cada vez más lúcida y resueltamente reivindicatoria de las necesidades de los dominados, que son mayoría:

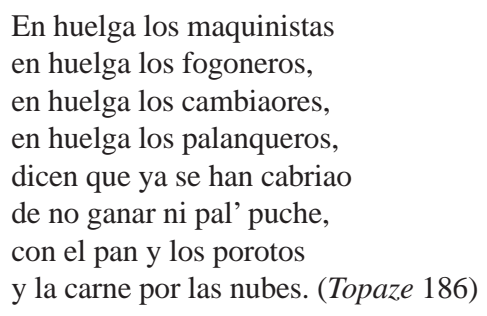

El correlato social que se desprende constituye un contradiscurso que legitima imágenes de caos, capaces de justificar el levantamiento de los más pobres y aun el robo generalizado:

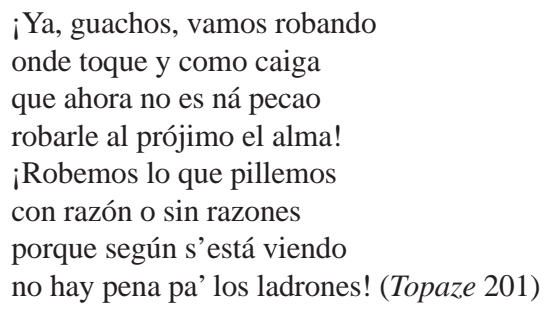

La discordancia entre los principios oportunistas y egoístas que mueven al poder político y aquéllos que verdaderamente debería promover y cumplir (establecer las condiciones para generar el bien común), conlleva a la construcción de un registro donde un imaginario de confusión, abusos y de marcada exclusión se impone. Posiblemente la contraviolencia que despliega el agitador y exclamativo “ ¡Robemos lo que pillemos!”, en los versos recién citados, no es sino una forma de resistencia que, en el marco de los años en los cuales Meléndez escribió en Topaze se transformó en un registro necesario al interior de otro mayor: aquel de los relatos libertarios, a menudo más próximos a programas político-colectivistas.

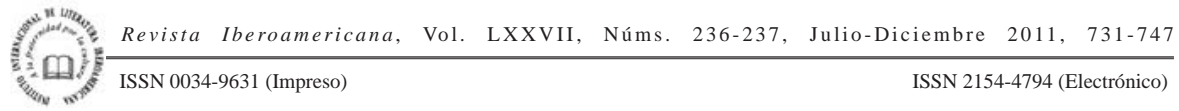


Nótese cómo el discurso heterogéneo de Meléndez reorganiza textos sociales desde la perspectiva de los sectores dominados, mediante formas comunicativas y focalizaciones propias del circuito popular:

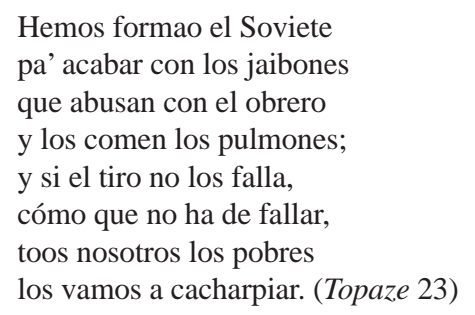

La conformación de este Partido Obrero, de raíz criolla, desliza un campo de producción discursivo que evidentemente se cruza con el relato mayor. La verbalización de un mundo asumido por el sujeto explotado condiciona un registro discursivo donde se apela a la conciencia del proletariado por asumir una misión histórica en directa referencia con la Revolución Soviética.

La imagen del desorden político que marcó al país durante los primeros años de la década del 30 se convirtió, sin embargo, en el discurso reiterado en las páginas de Meléndez. Los inicios de la República Presidencial en Chile, no estuvieron alejados de fuertes crisis. En 1930 el país vivió los efectos de la depresión económica mundial. La disminución del consumo de salitre chileno en el extranjero agudizó la desvalorización del mineral. 1931 fue un período durísimo. La crisis financiera y económica mundial se manifestó ostensiblemente, con grave daño para productores nacionales, comerciantes y consumidores. El 23 de julio de ese año se produjo una huelga agresiva, en contra del gobierno, por parte de estudiantes universitarios. Sobrevino la confusión, insubordinación de los poderes militares y el paro de industrias y del comercio. Carlos Ibáñez del Campo, presidente a la fecha, dimitió el 26 de julio. Los años siguientes no estuvieron exentos de dificultades. El alza en el costo de la vida dejaba oír reclamos y protestas. La sublevación de las fuerzas aéreas bajo las órdenes de Marmaduke Grove, el 4 de junio de 1932 puso fin al breve gobierno de Juan Esteban Montero (mediados de 1931, mediados de 1932). La "República Socialista de Chile", proclamada por una Junta heterogénea cuya duración fue de doce días (Carlos Dávila, Matte Hurtado y el general Arturo Puga) disolvió el Congreso.

El corto gobierno de Carlos Dávila que continuó al de la Junta Socialista llegó a su fin el 13 de septiembre del aquel mismo año, como consecuencia de un nuevo movimiento militar. Al tormentoso período de año y medio, le siguió el segundo gobierno de Arturo Alessandri (1932-1938). La baja del valor de la moneda circulante estimuló la exportación, pero decreció la importación. Esto creó en el mercado perturbaciones

Revista Iberoamericana, Vol. LXXVII, Núms. 236-237, Julio-Diciembre 2011, $731-747$
ISSN 2154-4794 (Electrónico) 
de distinto orden. Por otro lado, el estado sanitario del país, que la cesantía y la miseria profundizaban, llegó a ser deplorable. En 1933 el tifus adquiría, alarmantemente, caracteres de plaga. La indisciplina social predispuso al descontento y a las exigencias perentorias de los clamores públicos. La situación de relativa tranquilidad política que vivió Chile hacia mediados de los años 30, se vio interrumpida el 5 de septiembre de 1938, por un intento de rebelión alentada por la Vanguardia Popular Socialista. La casa central donde funcionaban las oficinas del Seguro Obrero, en Santiago, fue el escenario de un drama político de enormes consecuencias: la muerte de más de 60 jóvenes. Por consiguiente, una década marcada por tales circunstancias sirvieron de cláusula obligatoria a un discurso social de características movilizadoras y capaz de expresar la evidencia de la crisis política, social y del capital que afectaba, directamente, a las mayorías.

Aquel estado de la vida sociopolítica del país, la poesía de Meléndez lo volvió en un tópico que lo mostró mediante signos de absoluta turbación:

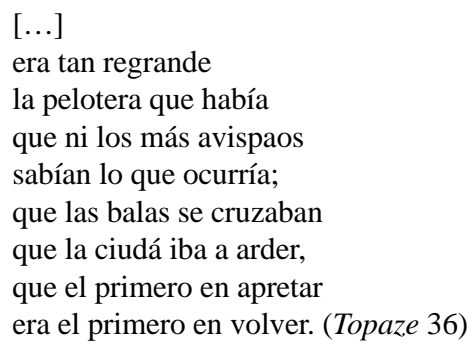

En otro momento, lo desarrolló mediante imágenes de descontrol y violencia, acciones generadas por los propios políticos:

Parece que juera un sueño

lo que vi no sé que día

en la Cámara Termal

[...]

Y aquí empezó el tiroteo

el repatagüino y grande

a golpes de tinterazos

y amenazas por el aire

¡Que se vaya el presidente

que atropelló el reglamento!

¡Que se vaya, que renuncie!

-¡Ándate vos, cosachento!

¡Mueran los del contubernio

conservador radical! (Topaze 40)

$\begin{array}{lllll}\text { ISSN 0034-9631 (Impreso) } & \text { Revista Iberoamericana, Vol. LXXVII, Núms. 236-237, Julio-Diciembre 2011, 731-747 }\end{array}$ 
Con ironía, otras veces, tematizóla incapacidad del presidente Juan Esteban Montero para satisfacer los requerimientos históricos de los pobres y para neutralizar el poder oligárquico dominante:

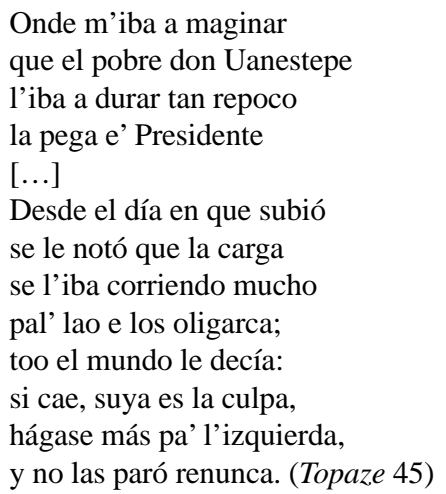

Los doce días de duración que tuvo la República Socialista de Chile, instaurada después de la insurrección liderada por el comodoro Marmaduke Grove -aludido en los versos que siguen como "Mameluco"- no hicieron más que profundizar la imagen de confusión, derechamente desmoralizadora para el hablante. Se trata de una posibilidad abortada que tampoco dio respuesta a la crisis, a las esperanzas de cambio y, sobre todo, a las necesidades de los más pobres:

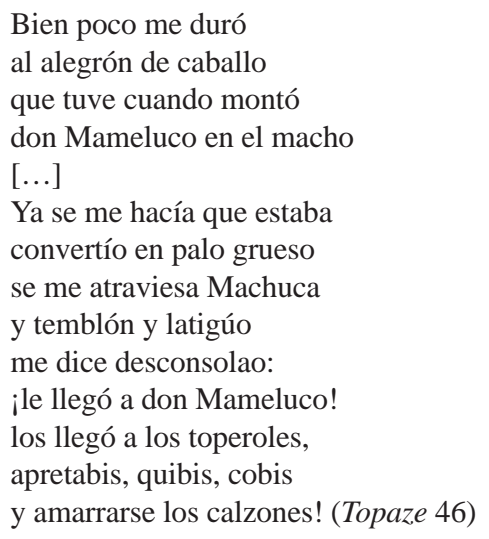

La carencia de lucidez que observa Meléndez en los gobiernos de la época, le llevó a recrear una realidad deformada y en absoluto desequilibrio. La relativización de valores

Revista Iberoamericana, Vol. LXXVII, Núms. 236-237, Julio-Diciembre 2011, $731-747$
ISSN 0034-9631 (Impreso) 
que observó el poeta desde la perspectiva de Juan Verdejo, no hizo sino profundizar la vaguedad de sentidos y el derrumbe de organización política. Quién sabe si en diálogo con el tango del argentino Enrique Santos Discépolo, Cambalache, los versos de Meléndez acumulan los mismos sentimientos de desengaño, donde un registro paródico e irónico ubica a hombres públicos (políticos y religiosos), animales y objetos en un mundo totalmente desarticulado. Si se sigue al estudioso José Gobello, de la Academia Porteña del Lunfardo, el tango Cambalache fue "estrenado por la orquesta de Francisco Canaro y su cantor Ernesto Famá en el filme Alma de bandoneón, Argentina Sono Film, 1935” (211). Acorde con esta información, los versos de Meléndez habrían constituido un proto espíritu "cambalachero". No obstante, Ernesto Sábato reconoce que ya hacia 1924, un poema publicado en la revista Martín Fierro, contiene toda la atmósfera de confusión que caracterizó el sentimiento de Discépolo frente a coyunturas históricas de los años 20 y 30 en Argentina (147). Sea uno u otro el caso, lo importante es reconocer cómo al interior de los discursos sociales se cruzan pluri-registros:

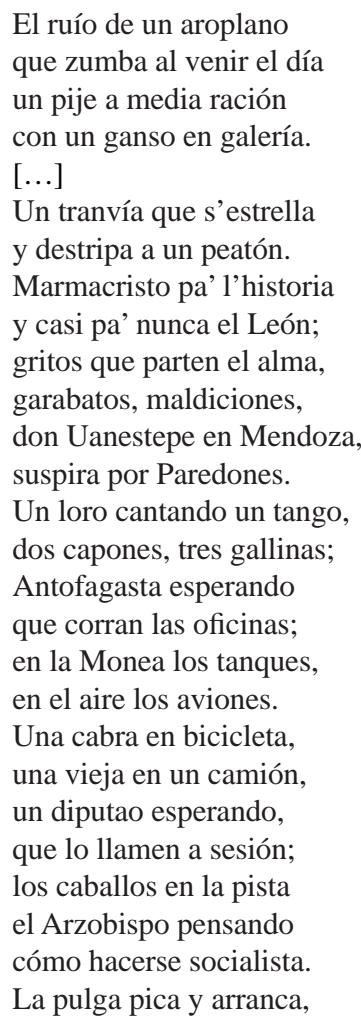




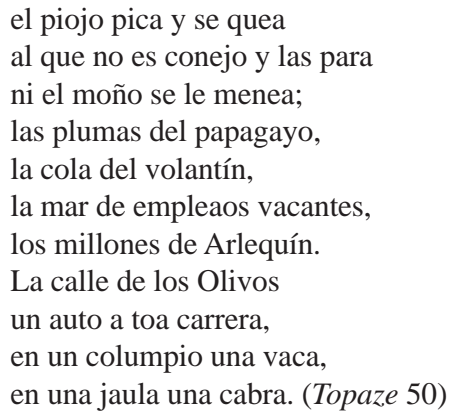

En este mismo marco, otros grupos ideológicos de la vida pública de Chile de los años treinta, aparecen igualmente multiplicando el desorden institucional:

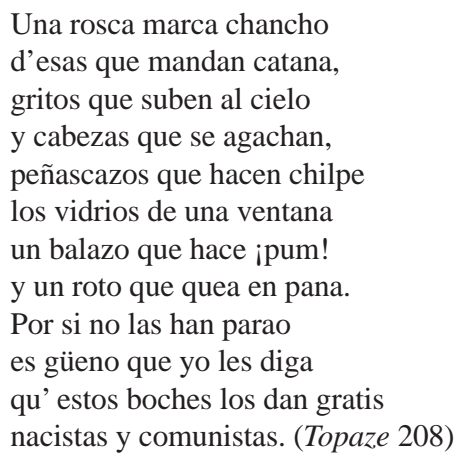

Hacia fines de la década de los años treinta, época del gobierno de Arturo Alessandri, el programa conocido como "el resurgimiento", encaminado a controlar la crisis y, fundamentalmente satisfacer las demandas de los sectores más necesitados, no hizo más que -paradójicamente- acrecentar los dos extremos del orden social, condenando con fiereza aún más a los pobres:

Pero después d'estos años

de feroz resurgimiento

en que uno se ha puesto curco

viendo si pesca algún peso,

ha cambiao el conventillo

porque los que no se han muerto

andan que apenas si pueden

sostener el esqueleto. (Topaze 239; énfasis mío)

ISSN 0034-9631 (Impreso) 
Quizá como un llamado a despertar la conciencia proletaria, Meléndez, al cierre del año 38, saca cuentas negativas para los deseos de las masas. Pese al desfile de gobiernos, las expectativas reales de cambios han sido nulas. Con ironía, el resurgimiento de Alessandri o "florecimiento", según los versos del poeta, ha asentado aún más el engranaje inexorable de los poderosos, los pobres siguen esperando:

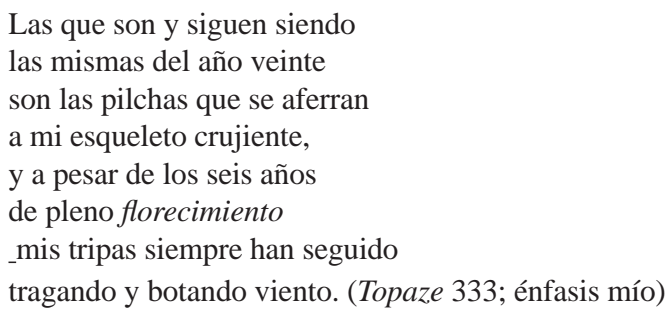

Hasta mediados de 1942, último período de la participación de Héctor Meléndez en la revista Topaze, sus versos mantuvieron el afán por representar el imaginario y la sensibilidad popular-masivos y, además, reivindicar, a través del discurso heterogéneo que le caracterizó, a los excluidos. Guardó de este modo, aún en el contexto de los gobiernos de Pedro Aguirre Cerda y Juan Antonio Ríos (cuyos proyectos socio-políticos desarrollaron diversas acciones públicas en favor de la mayoría), el repertorio vinculado con la figuración de las carencias frente a las cuales siguieron expuestas las masas pobres de la ciudad. Condiciones, éstas, no siempre declaradas por los modos de producción comunicativa y recepción hegemónico-ilustrados. Por esta razón no es infundado postular que la poesía de Meléndez en Topaze representó una voz de resistencia y también un llamado a la resistencia. En sus versos, los rotos urbanos siguieron esperando cambios; para ellos, la vida fue la de siempre. Cada una de las reglas del juego del organismo social heterogéneo se hizo en los versos de Meléndez expresión y memoria.

Las privaciones y deficiencias alimenticias, la insalubridad, el alcoholismo y aun la prostitución aparecen invariablemente en la vida de los conventillos. Lo que queda es resistir. En “Otoño”, un texto de marzo de 1942 (Topaze 500), continúa leyéndose la denuncia social y política. La tonalidad de sus octosílabos poseen un extraordinario valor composicional y temático. Los males recién apuntados se sugieren a través de imágenes que movilizan una lectura crítica de la realidad. El pathos que las potencia genera la recreación de un espacio social descarnado, problemático y, aunque miserable, líricamente conmovedor:

Ya viene asomando el frío con su poncho de neblina, la mañana se acolchona, la noche se come el día;

Revista Iberoamericana, Vol. LXXVII, Núms. 236-237, Julio-Diciembre 2011, $731-743$
ISSN 2154-4794 (Electrónico) 


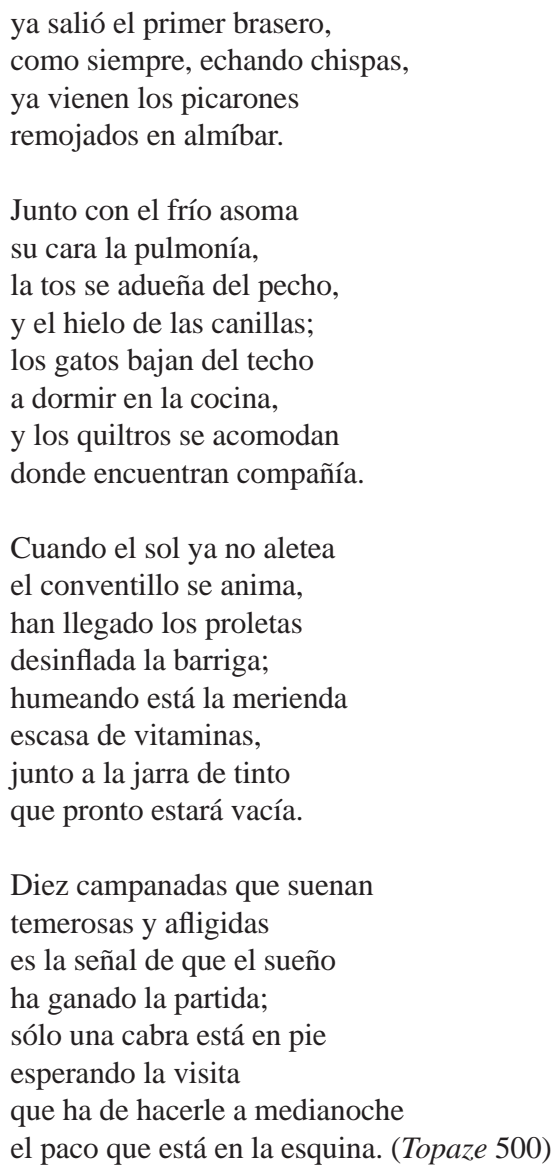

Sobre la base de todo aquello comentado más arriba se podría preguntar: ¿Dónde queda algún lugar para la reivindicación de los más pobres y las proposiciones alentadoras de cambio y des-jerarquización de la estructura dominante? La respuesta es evidente. Una dimensión fecundamente social de la poesía popular radica en que las posibilidades de cambio se abren a, porque vienen también de, penurias colectivas. Así, todo discurso de denuncia crítica y de alcance masivo, nutre más la ilusión que el desencanto. Redunda, por ende, en la promoción, aunque utópica, de cambios: “Toda tensión innovadora proviene de quienes cuestionan el orden imperante a partir de una necesidad o un ‘deseo no satisfecho’ y no de los privilegiados y saciados” (Ainsa 53).

Revista Iberoamericana, Vol. LXXVII, Núms. 236-237, Julio-Diciembre 2011, 731-743
ISSN 2154-4794 (Electrónico) 
El poeta popular, cuando "habla" por los marginados y oprimidos es, por esto, una voz esperanzada y esperanzadora.

Por consiguiente, la imaginería popular se insertó en las páginas de la revista Topaze como un fenómeno comunicativo-significativo del tipo heterogéneo y movilizador. Es más, interactuó con otros circuitos o sistemas que no siempre habían valorado lo masivo como parte de la definición de la identidad nacional, ampliando el campo de la cultura y recepción de la misma. Observado desde esta perspectiva, el registro "MeléndezTopaze" no deja de remitir a un proceso dinámico, respecto de los modos tradicionales de producción cultural. Como lo reconoce Manuel Antonio Garretón, por ejemplo, "la noción de pueblo dio un contenido diferencial al concepto abstracto de ciudadano" (24). La vida de los rotos de la ciudad, junto con sus discursividades y narrativas, se dirigió de este modo a sectores más amplios del país constituyendo, con esto, otros cruces culturales. En Chile, durante la década de los años 30, los repertorios tópicos de la poesía de Héctor Meléndez así lo demostraron.

\section{OBRAS CITADAS}

Ainsa, Fernando. La reconstrucción de la utopía. Buenos Aires: Ediciones del Sol S.R.L., 1999.

Angenot, Marc. Interdiscursividades. De hegemonías y disidencias. Córdoba: Editorial Universidad Nacional de Córdoba, 1998.

"El hombre más feo de Chile”. Sucesos (6 septiembre 1902): 14-15

Garretón, Manuel Antonio et al. El espacio cultural latinoamericano. Santiago de Chile: Fondo de Cultura Económica Chile S.A., 2003.

Gobello, José. Letras de tangos. Buenos Aires: Centro Editor de Cultura Argentina, 1999.

Guerra, Lucía. Texto e ideología en la narrativa chilena. Minneapolis: Prisma Institute, 1987.

Martín-Barbero, Jesús. Oficio de cartógrafo. Travesías latinoamericanas de la comunicación en la cultura. Santiago de Chile: Fondo de Cultura Económica Chile S.A., 2002.

Meléndez, Héctor. “Tallas Populares. Juan Verdejo.” Topaze 11 (1931). "Verdejo mandando el Buque". Verdejo (4 de octubre 1932): 2-3. “Tallas Populares.” Juan Verdejo. Topaze 23 (1932). “Tallas Populares.” Juan Verdejo. Topaze 27 (1932). “Tallas Populares.” Juan Verdejo. Topaze 36 (1932). “Tallas Populares.” Juan Verdejo. Topaze 40 (1932). “Tallas Populares.” Juan Verdejo. Topaze 45 (1932). “Tallas Populares.” Juan Verdejo. Topaze 46 (1932). “Tallas Populares.” Juan Verdejo. Topaze 50 (1932). “Tallas Populares.” Juan Verdejo. Topaze 95 (1933). 
“Tallas Populares.” Juan Verdejo. Topaze 186 (1936).

“Tallas Populares.” Juan Verdejo. Topaze 201 (1936).

“Tallas Populares.” Juan Verdejo. Topaze 208 (1936).

“Tallas Populares.” Juan Verdejo. Topaze 220 (1936).

“Tallas Populares.” Juan Verdejo. Topaze 239 (1937).

“Tallas Populares.” Juan Verdejo. Topaze 333 (1938).

“Tallas Populares.” Juan Verdejo. Topaze 500 (1942).

Montealegre, J. “Humor Gráfico y delincuencia.” Patrimonio Cultural(Santiago de Chile) 20 (2001): 20-29.

Sábato, Ernesto. Tango, discusión y clave. Buenos Aires: Losada, 1968.

Revista Iberoamericana, Vol. LXXVII, Núms. 236-237, Julio-Diciembre 2011, 731-747 
